\title{
テクタイトに関する最近の資料 (3)
}

柴田勇

テクタイトについては引続き多くの報文や論説 が出ており，その主なものについては逐次紹介し てきたが，最近また注目すべきものがいくつか見 当つたので簡単にノートし併せて筆者の見解を述 ベておこう。

これまで知られていたテクタイトの化学組成 は，地域的にも時代的にも大体類似したものであ り, $\mathrm{SiO}_{2} 68 \%$ から $80 \%$ くらいのものであつた。 ところが最近になって，テクタイトにはもつと低 シリカ高マグネシアのものがあることが判明した のである。

豪州寄りの印度洋海域およびアフリカ象牙海岸 沖で, 深海堆積物コアー中に発見された微小テク タイト(microtektite) は, その物理性・化学性・ 生成時期などからして，それぞれ豪州産および象 牙海岸産のテクタイトと同じメンバーのものであ ることが論証された。ただ，正常のテクタイトと 異る点は, それらが $1 \mathrm{~mm}$ 以下の顕微鏡的大きさ のものであることと，化学組成にちがいのあるこ とで，形状・習癖などはそれぞれの地域のテクタ イトと大体同じである。

象牙海岸沖のものは (Glass, B. 1967，1969) $\mathrm{SiO}_{2} 67 \sim 49 \%$, salic oxides $86 \sim 67 \%$, femic oxides $12 \sim 32 \%$ で, このうち正常のテクタイト に近い組成の(但し，やや $\mathrm{SiO}_{2}$ の少ない)ものは 扱つたうちの約 $84 \%, \mathrm{SiO}_{2}$ 53\%以下で $\mathrm{MgO} 16$ 〜21\%のものは約 $5 \%$, 両者の中間的組成のもの は約 $11 \%$ あつた。

豪州寄り印度洋産のものも (Cassidy, W. A. ほか，1969）これ之ほぼ同様のグループに分けら れ，豪州産テクタイトに似た組成のものが $65 \%$ ， 低シリカ高マグネシア型が $5 \%$, 中間型が $30 \%$ と なっている。

いずれの地域においても, 低シリカ高マグネシ ア型は bottle green であり, 比重ならびに屈折 率は正常型のものより高い。そして，テクタイト
および微小テクタイトの $\mathrm{Na}_{2} \mathrm{O} / \mathrm{K}_{2} \mathrm{O}, \mathrm{MgO} / \mathrm{CaO}$ は両地域において相異があり（それぞれの地域で は同じ), 時代の相異と共に，それぞれが別個の グループに属することを示している。

要するに, 微小テクタイトは在来のテクタイト と一連のもので, より $\mathrm{SiO}_{2}$ の少ない部類に属す るものらしく,これによりテクタイトは $\mathrm{SiO}_{2}$ だ けについて言えば, 地球上の岩石では基性火山岩 から酸性火山岩までの range のものであること になる。しかし, 地球上のこれら火山岩とは化学 成分の trend がかなりちがつている。ここで改 めて世界各地産のテクタイトの化学組成を表示す る。

Barnes (1969) によると, moldavite には屈折 率の差により撒布地域内で帯状分布が認められ， 他の産地のテクタイトでも区域による組成の差異 が認められるところがある。また，象牙海岸地域 のテクタイトとその沖合に分布する微小テクタイ トでは多少組成のちがいが認められている（表参 照)。このような事実から 考えると，一つの時期 に飛来したテクタイトでも, 質量(大きさ)の差も しくは比重の差により, 大気圈侵入後の飛行コー スに僅かな差異を生じ，これが撒布区域の dispersion をもたらすのかもしれない。

今までに採取された月の岩石は斑粝岩質（玄武 岩質）のものが多く，この点テクタイト物質の月 起源説には都合が悪いように思われるが, 今後低 シリカ苦鉄質のテクタイトがもつと発見される可 能性もあり,またもし月の別の部分で広範囲に酸 性火成岩質のところがあり，そのような場所にお ける隕石衝撃によつて放出された月面物質が，宇 宙力学的に最もよく地球に飛来するものであるな らば，現在までのテクタイトの組成的偏倚が説明 できるのではなからうか。今後資料の集積が望ま れる。 


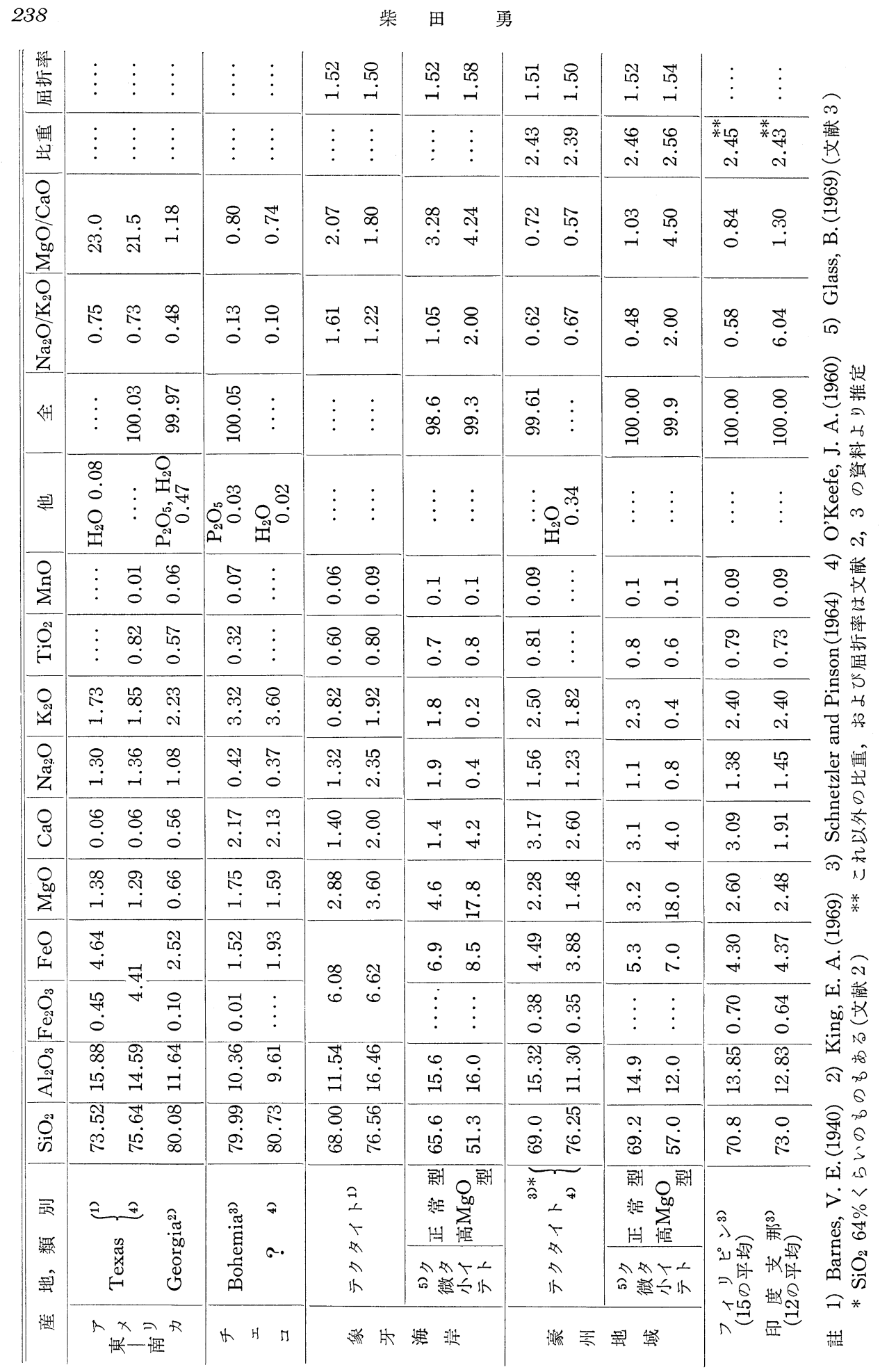




\section{文献}

1) Glass, B. P. (1967) : Microtektites in deep-sea sediments. Nature, 214, 372374.

2) Glass, B. P. (1969) : Chemical composition of Ivory Coast microtektites. Geochim. Cosmoch. Acta. 33(9) 11351147.

3) Cassidy, W. A., Glass, B. P. and Heezen, B. C. (1969) : Physical and chemical properties of Australasian microtektites. J. Geophys. Res. 74 (4) 1008-1025.

Geochim. Cosmoch. Acta 33(9) にはな お次の論文むある。

4) Compston, W. and Chapman, D.
R. : Sr isotope patterns within the southeast Australasian strewn-field. 同地 域テクタイトの $\mathrm{Rb}, \mathrm{Sr} .{ }^{87} \mathrm{Sr} /{ }^{86} \mathrm{Sr}$ を測定, 大体化学的性状のグループ毎に等時性が ある事学見。

5) TAYLOR, S. R. and KAYE, M.: Genetic significance of the chemical composition of tektites: A review. テクタイト の組成は，その主成分と微量成分元素で, 地球上の砂岩と強い類似性がある.

6) BARnes, V. E.: Petrology of moldavite. チェコ内に括ける moldavite は, 西のBohemia 域と東の Moravia 域とで 僅かながら組成の差異があり（後者の方が 平均してシリカ多し), またそれぞれにお いて屈折率の帯状分布がある. 